\title{
Profitability of Investment in Plantain Value Chain in Osun State, Nigeria
}

\author{
Oke Joel Taiwo Oluseye, Ogunleye Ayodeji Sunday*, Kehinde Ayodeji Damilola
}

Department of Agricultural Economics, Faculty of Agriculture, Obafemi Awolowo University, Ile Ife, Nigeria

Email address:

ogunleyedeji@yahoo.co.uk (O. A. Sunday)

${ }^{*}$ Corresponding author

\section{To cite this article:}

Oke Joel Taiwo Oluseye, Ogunleye Ayodeji Sunday, Kehinde Ayodeji Damilola. Profitability of Investment in Plantain Value Chain in Osun State, Nigeria. Ecology and Evolutionary Biology. Vol. 4, No. 2, 2019, pp. 23-27. doi: 10.11648/j.eeb.20190402.13

Received: January 29, 2019; Accepted: March 8, 2019; Published: September 27, 2019

\begin{abstract}
Profit is the driving force for any enterprises to thrive well, because it encourages more investment into an enterprise. One of the major barriers to investing in plantain value chain is inadequate information on return to investment. Thus, this paper investigated profitability of investors along plantain value chain in Osun state. A multistage sampling procedure was used to elicit information from 100 respondents for the study. Data were analysed using descriptive analysis, budgetary analysis, and multiple regression analysis. Descriptive statistics reveal that average age was $52.2( \pm 11.19)$ years for plantain farmers, $41.8( \pm 10.78)$ years for processors and marketers $33.42( \pm 11.99)$. While, average farming experience was $26.9( \pm 10.88)$ years for plantain farmers, $12.47( \pm 10.78)$ years for processors and marketers $5.84( \pm 19.12)$. About $6.7 \%$ farmers, $15.6 \%$ processors and $13.2 \%$ marketers had access to credit facilities. The budgetary analysis showed that benefit-cost ratios were $\$ 1.38, \$ 1.30$ and $\$ 1.19$ for the farmers, processors and marketers, respectively. Multiple regression estimates revealed that insecticide used $(\mathrm{p}<0.1)$ and numbers of plantain harvested $(\mathrm{p}<0.01)$ significantly influenced the profitability of the plantain farmers, while age $(\mathrm{p}<0.1)$, level of formal education $(\mathrm{p}<0.05)$, amount invested into the business $(\mathrm{p}<0.01)$ and household size $(\mathrm{p}<0.05)$ significantly influenced the profitability of the plantain marketers. Only household size $(\mathrm{p}<0.01)$ significantly influenced the profitability of the plantain processor. In accordance with the findings of the study, we therefore recommend that subsidized cost of inputs and better access to credit among the investors along the value chain would increase the level of return to the investment.
\end{abstract}

Keywords: Profitability, Plantain, Value Chain, Investment

\section{Introduction}

Plantain (Musaceae paradisiaca) is an important starchy fruit crop. It is ranked fourth world most important food crop after rice, wheat and maize grown in the Humid Tropics areas of the World such as Africa, Asia, Central and North America [1-2]. Plantain production in Nigeria accounted for more than 50 percent of world production [3]. Recent statistics on plantain production placed Nigeria $(2,722,000$ metric tonnes) at first position in Africa and fifth in the world [3-4]. This is attributed to the fact that investment in plantain enterprise could alleviate rural poverty as well as ensure food security [5]. This could be ascribed to the fact that plantain is a multipurpose crop with great processing potential.

Plantain has low saturated sugar (220 calories), sodium content, and minerals that are essential to human being when consumed raw. It is a good source of potassium, magnesium, phosphate, dietary fibre, and vitamins such as vitamin A, B6 and $\mathrm{C}$ that aid vision, good skin and immunity. Due to its high nutrients content, plantain can be used in the treatment of some ailments such as sore throats, tonsillitis, diarrhoea, vomiting, and kwashiorkor [6]. The fresh juice from plantain trunk, fruit stalk and leaves are healing and soothing remedy to burns and anti-bleeding on wounds [7].

Apart from raw consumption, plantain could be processed into various value-added products such as flour, beverages, chips, juice, jams, soft drink depending on the maturity and ripeness of the plantain fruit [8]. The immature fruits are peeled, sliced, dried, processed into powder and consumed as plantain flour. The mature fruits (ripe or unripe) are 
consumed boiled, steamed, baked, pounded, roasted, or sliced and fried into chips. Overripe plantains are processed into beer or spiced with chilli pepper, fried with palm oil and served as snacks popularly known as dodo-ikire. Also, plantain leaves are used for wrapping, packaging, marketing and serving of food. Apart from its usefulness to human being, it could be used as animal feeds for livestock's and manure and mulching materials for plants

In the light of foregoing, it is evident that plantain is a reliable source of revenue as well as raw material to agroindustries producing its value-added products. As a result, a lot of Nigerians invest huge amount of money into plantain enterprises to generate substantial income. Investment in plantain enterprise could be in form of cultivation, processing or/and marketing of plantain. Despite the huge capital invested into the enterprise, investors are not realising a reasonable profit that commensurate with their effort and level of investment. Also, PIND [9] noted that marketers gain more than other actors in the value chain due to weak coordination along the value chain. This was often ascribed to some complex set of factors such as infestation of pest and diseases, poor management practices, poor road network and lack of storage facility, and short storage life [10-12]. Since all investors invest huge capital in plantain value chain, it becomes imperative to investigate the returns to each investor along the value chain. Consequently, this paper investigates profitability of investment in plantain value chain in Osun State, Nigeria. Specifically, describes the socio-economic characteristics of the plantain investors, determines the profitability of investors in plantain value chain, and determines the factors affecting the profitability of investors in plantain value chain.

\section{Metholody}

\subsection{Study Area}

This study was carried out in Osun State, Southwestern part of Nigeria. The State lies within latitudes $6^{\circ}$ and $7^{\circ} \mathrm{N}$ of the equator and approximately between longitudes $4^{\circ}$ and $5^{\circ} \mathrm{E}$ of Greenwich meridian [13]. It is one of the land- locked states of the Federal Republic of Nigeria, bounded in the West of Oyo State, in the East by Ondo State, in the North by Kwara State and in the south by Ogun State. It covers an estimated area of 9251 square kilometre [14]. The predominant occupation of the State is farming. The crops grown include yam, cassava, maize, rice, cowpea, and perennial crops such as cocoa, kolanuts, plantain, and oil palm.

\subsection{Sampling Procedure}

Multistage sampling procedure was used to obtain data for the study. The first stage involved purposive selection of three local Government Area (LGAs) based on the volume of plantain production in the areas. The LGAs include Atakumosa west, Irewole and Ife central. The second stage involved random sampling of three villages in each LGAs.
The third stage involved random selection of thirty plantain farmers, thirty-two processors with thirty-eight marketers from the villages. An individual was considered to be a plantain farmer and marketer if he engages in planting and marketing of plantain, respectively. A processor, if the individual is involved in "dodo Ikire", plantain chip, plantain flour and roasted plantain. A total of one hundred plantain investors were used for this study.

\subsection{Analytical Technique}

\subsubsection{Descriptive Statistics}

Descriptive statistics such as percentages and mean were used to describe the socioeconomic characteristics of respondents.

\subsubsection{Budgetary Analysis}

The gross margin analysis was used to estimate the cost and return accruing to each stage in plantain value chain in the study area. The gross margin analysis was calculated by using the formula below:

$$
\begin{gathered}
\text { GM }=\text { TR }- \text { TVC } \\
\text { Net revenue }=\text { TR }- \text { TC } \\
\text { Profit }=\text { GM }- \text { TFC (depreciated value) }
\end{gathered}
$$

Where, $\mathrm{TC}=\mathrm{TFC}+\mathrm{TVC}, \mathrm{GM}=$ Gross Margin, $\mathrm{TR}=$ Total Revenue, $\mathrm{TC}=$ Total Cost, $\mathrm{TFC}=$ Total fixed cost, $\mathrm{TVC}=$ Total variable cost.

\section{Benefit-cost ratio (BCR)}

This measures the rate of returns to the total cost incurred on production [15]. The formula is as follows:

$$
\mathrm{BCR}_{\mathrm{i}}=\frac{\text { Net Profit Margin }}{\mathrm{i}}
$$

\subsubsection{Multiple Regression Model}

Multiple regression model was used to determine the factors affecting the profitability of investment in plantain value chain. The implicit function was expressed thus:

$$
\mathrm{Y}=\mathrm{F}\left(\mathrm{X}_{1}, \mathrm{X}_{2}, \mathrm{X}_{3}, \mathrm{X}_{4}, \mathrm{X}_{5}, \mathrm{X}_{6}, \mathrm{X}_{7}, \mathrm{e}_{\mathrm{i}}\right)
$$

Where;

$\mathrm{Y}=$ Profitability level at each stage in the plantain value chain; $\mathrm{X}_{1}=$ Age (Years); $\mathrm{X}_{2}=$ Educational level of respondent (Years); $\mathrm{X}_{3}=$ Insecticide cost (\$); $\mathrm{X} 4=$ Household size; $\mathrm{X} 5=$ Raw plantain cost $(\$) ; \mathrm{X}_{6}=$ Cost of plantain harvested $(\$) ; \mathrm{X}_{7}$ $=$ Amount invested into the business $(\$)$; and $\mathrm{e}_{\mathrm{i}}=$ Error term.

\section{Result and Discussion}

\subsection{Socio-economic Characteristics of Investors}

The socioeconomic characteristics of plantain farmers were presented in Table 1. The average age was 52.2 $( \pm 11.19)$ years, $41.8( \pm 10.78)$ years and $33.42( \pm 11.99)$ years for plantain farmers, processors, and marketers, respectively. This implies that the processors and marketers are relatively young. This could indicate that they are energetic and 
innovative [16]. The result further implies that an average farmer in the study area is relatively old. This could be attributed to the fact that older people generally stay in the villages and relatively younger people go to cities for education, learning of trade and in search of white-collar jobs. Distribution by gender revealed that about $93.3 \%$ of the farmers are male. This could indicate that plantain farming is masculine in nature. The processors $(100 \%)$ and marketers $(92.1 \%)$ are majorly female indicating the feministic nature of the job. It also shows suggest that the plantain processor and marketers is gender biased in favour of women. Only few of the plantain investors had tertiary education with $15.8 \%$ for the marketers, $6.3 \%$ for the processors and none for the farmers. This implies that majority of the respondents are illiterates. Though education is not a prerequisite to invest in plantain business, it could provide the investors with enough skills and innovation to improve their plantain business. About $93.3 \%$ of farmers, $100 \%$ for processors and $73.7 \%$ of marketers are married. This implies some level of responsibilities into farming business to meet up with family needs. The average farming experience was $26.9( \pm 10.88)$ years, $12.47( \pm 10.78)$ years and $5.84( \pm 19.12)$ years for plantain farmers, processors, and marketers, respectively. This indicates that the respondents have many years of experience their respective businesses. This could have a positive effect on the plantain business. Only $6.7 \%$ farmers, $15.6 \%$ processors and $13.2 \%$ marketers had access to credit facilities. This implies that the investors have limited access to credit facilities. This reiterated the fact that plantain enterprises are maintained by personal funds and cash remittance from friends.

Table 1. Socio-economic Characteristics of Investors.

\begin{tabular}{llll}
\hline Variables & Farmers $(\mathbf{n = 3 0})$ & Processors $(\mathbf{n}=\mathbf{3 2})$ & Marketers $(\mathbf{n = 3 8})$ \\
\hline $\begin{array}{l}\text { Age (years) } \\
\text { Gender (\%) }\end{array}$ & $52.2(11.95)$ & $41.78(10.78)$ & $33.42(11.99)$ \\
Male & 93.3 & 0 & 7.9 \\
Female & 6.7 & 100 & 92.1 \\
Year of schooling (\%) & & & 57.9 \\
Less than 9 & 96.6 & 62.5 & 15.8 \\
$10-12$ & 0 & 6.3 & 15.8 \\
$12-18$ & 0 & 6.3 & 73.7 \\
Married (\%) & 93.3 & 100 & $12.47(10.78)$ \\
Experience (years) & $26.9(10.88)$ & 15.6 & $5.82(19.12)$ \\
Access to credit & 6.7 & & 13.2 \\
\hline
\end{tabular}

Note: Figures in parentheses are standard deviations

Source: Field Survey, 2015

\subsection{Profitability of All Investors in Plantain Value Chain}

The distribution of various costs incurred and returns to all investors in plantain value chain were presented in Table 2. The analysis was computed on twelve (12) months basis for farmers. Budgetary analysis encompasses cost components such as average fixed cost and average variable costs of variable cost of various categories and production income i.e. total income or total revenue. In this study, the monetary value of the outputs was obtained. From the computation, the average total variable cost was $\$ 66.783, \$ 90.079, \$ 30.653$ for the farmers, processors and marketers, respectively. While, the average fixed cost was \$25.76, \$1.004, \$ 3.961 for the farmers, processors and marketers, respectively. The total revenue was $\$ 128.165, \$ 118.489, \$ 41.268$ for the farmers, producers and marketers respectively. The gross margin to each enterprise were \$61.382, \$28.392, \$10.615 for the farmers, processors and marketers, respectively. This shows that all the investors (farmers, processors and marketers) along the plantain value chain were making profit. This indicates that the investors were able to cover all variable cost incurred in course of production. The average net income was $\$ 35.622 ; \$ 27.388$ and $\$ 6.654$ for the farmers, processors and marketers, respectively. This could indicate that the plantain business is profitable at each stage of investment. The benefit ratio was $\$ 1.38, \$ 1.30$ and $\$ 1.19$ for the farmers, processors and marketers respectively. This implies that every $\$ 100$ invested in the enterprise yield additional $\$ 138, \$ 130$ and $\$ 119$ for the respective investors. This implies that investors were making profit at each level along the value chain. However, the most enterprising sector in plantain value chain is production followed by processing, while marketing is the least in the study area.

Table 2. Profitability of all Investors in Plantain Value Chain.

\begin{tabular}{|c|c|c|c|c|c|}
\hline \multicolumn{2}{|l|}{ Farmers $(n=30)$} & \multicolumn{2}{|c|}{ Processors $(n=32)$} & \multicolumn{2}{|l|}{ Marketers (n=38) } \\
\hline Items & Amount (\$) & Items & Amount (\$) & Items & Amount (\$) \\
\hline Insecticide (lit/ha) & 36.096 & Raw plantain & 63.290 & Plantain product & 9.817 \\
\hline Herbicides (lit/ha) & 21.44 & Palm oil & 3.52 & Transport & 0.230 \\
\hline Weeding & 3.328 & Vegetable oil & 9.851 & Repackage material & 15.209 \\
\hline Fertilizer (kg/ha) & 0.426 & Pepper & 0.745 & Sale person & 5.397 \\
\hline Bush clearing & & Salt & 0.300 & Total variable cost & 30.653 \\
\hline Fertilizer application & 3.84 & Nylon & 1.276 & Shop rent & 3.961 \\
\hline Herbicide application & 1.653 & Starch & 0.085 & Total fixed cost & 3.961 \\
\hline
\end{tabular}




\begin{tabular}{|c|c|c|c|c|c|}
\hline \multicolumn{2}{|l|}{ Farmers $(n=30)$} & \multicolumn{2}{|l|}{ Processors $(n=32)$} & \multicolumn{2}{|c|}{ Marketers (n=38) } \\
\hline Items & Amount (\$) & Items & Amount (\$) & Items & Amount (\$) \\
\hline Total variable cost & 66.783 & Sugar & 0.533 & & \\
\hline Cutlass & 0.16 & Colouring & 0.16 & & \\
\hline Building and farm rent & 25.6 & Onion & 0.390 & & \\
\hline \multirow{14}{*}{ Total fixed cost } & \multirow{14}{*}{25.76} & Pin & 0.186 & & \\
\hline & & Paper & 0.55 & & \\
\hline & & Telephone & 0.88 & & \\
\hline & & Fire wood & 3.179 & & \\
\hline & & Fuel & 2.592 & & \\
\hline & & Frying cost & 2.56 & & \\
\hline & & Total variable cost & 90.097 & & \\
\hline & & Bowl & 0.148 & & \\
\hline & & Knife & 0.052 & & \\
\hline & & Frying pot & 0.374 & & \\
\hline & & Spoon & 0.057 & & \\
\hline & & Sieve & 0.125 & & \\
\hline & & Basket & 0.248 & & \\
\hline & & Total fixed cost & 1.004 & & \\
\hline Total cost & 92.543 & Total cost & 91.101 & Total cost & 34.614 \\
\hline Total revenue & 128.165 & Total revenue & 118.489 & Total revenue & 41.268 \\
\hline Net revenue & 35.622 & Net revenue & 27.388 & Net revenue & 6.654 \\
\hline Gross margin & 61.382 & Gross margin & 28.392 & Gross margin & 10.615 \\
\hline Rate of return & 0.92 & Rate of return & 0.31 & Rate of return & 0.34 \\
\hline Benefit cost & 1.38 & Benefit cost ration & 1.30 & Benefit cost & 1.19 \\
\hline
\end{tabular}

Source: Field survey, 2015

\subsection{Factors Affecting the Profitability of Investors Along Plantain Value Chain}

Multiple regression estimates showed the level of significance of variables that were considered to be important factors influencing profitability of plantain enterprise (Table $3)$. Insecticides applied $(p<0.1)$ and numbers of plantain harvested $(p<0.01)$ significantly influenced profitability level among plantain farmers. The coefficients of insecticides applied $(p<0.1)$ and numbers of plantain harvested $(p<0.01)$ had positive signs, implying that for every unit increase in any of these variables increases the profitability level among plantain farmers by the magnitude of their coefficients; 4.240 and 3.258 units, respectively. Also, the positive coefficient of household size $(p<0.001)$ implies that this variable increases profitability level among plantain processors by the magnitude of its coefficient (0.629) units. Age $(\mathrm{p}<0.1)$, level of formal education $(\mathrm{p}<0.05)$, amount invested into the business $(p<0.01)$ and household size $(p<0.05)$ significantly influenced profitability level among plantain marketers. The coefficients of level of formal education $(p<0.05)$, amount invested into the business $(\mathrm{p}<0.01)$ and household size $(p<0.05)$ had positive signs, implying that for every unit increase in any of these variables increases the profitability level among plantain marketers by the magnitude of their coefficients; $0.407,0.610$ and 0.518 units, respectively. On the other hand, the negative coefficient of age $(p<0.001)$ implies that this variable decreases profitability level among plantain processors by the magnitude of its coefficient (0.381) units.

Table 3. Factors affecting the profitability of investors along the plantain value chain.

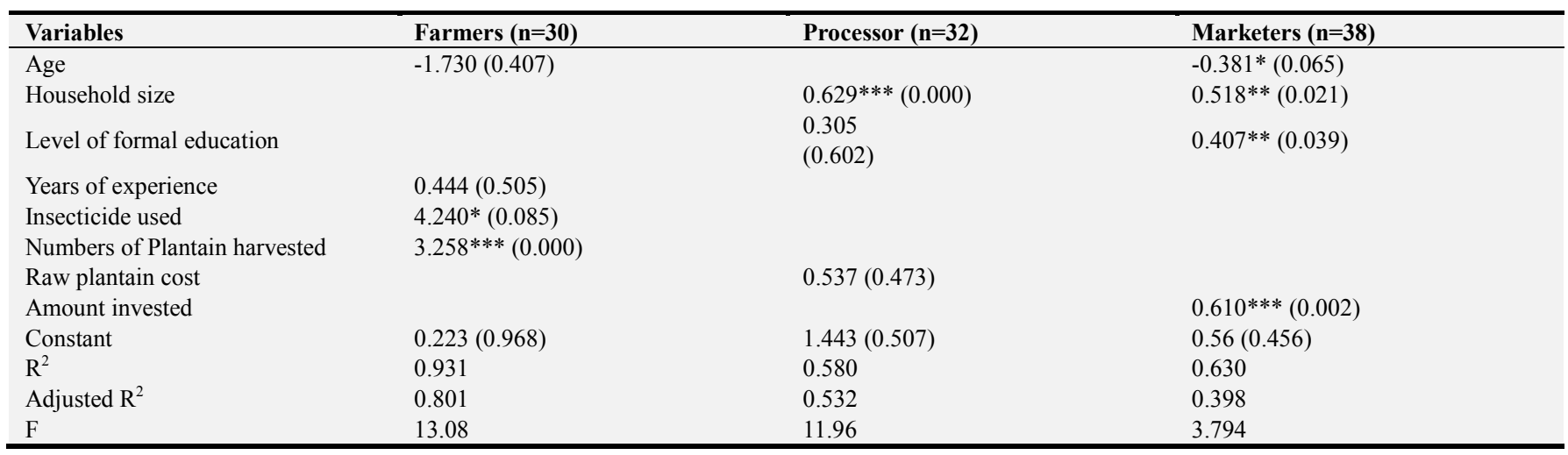

$* * *$ Significant at $1 \%, * *$ Significant at $5 \%, *$ Significant at $10 \%$. Figures in parentheses () are p-values. 


\section{Conclusion and Recommendation}

This paper investigated profitability of investment in plantain value chain in Osun State, Nigeria. Descriptive statistics showed that majority of the respondents are illiterate, experienced and married. Majority of the farmers are male, while plantain processor and marketers is gender biased in favour of women. The investors had limited access to credit facilities. Budgetary estimates revealed that plantain business is profitable at each stage of investment in the study area. However, the most enterprising sector in plantain value chain is production followed by processing, while marketing is the least in the study area. Insecticide used $(p<0.1)$ and numbers of plantain harvested $(p<0.01)$ significantly influenced the profitability of the plantain farmers, while age $(p<0.1)$, level of formal education $(p<0.05)$, amount invested into the business $(p<0.01)$ and household size $(p<0.05)$ significantly influenced the profitability of the plantain marketers. Only household size $(p<0.01)$ significantly influenced the profitability of the plantain processor. All these significant variables must be considered in an effort to increase profitability of investors along the value chain. Since the investment in plantain processing is labour intensive and highly profitable, efforts should be made to reduce the labour intensive through introduction of mechanization to avert inefficiencies resulting from use of labour. However, subsidized cost of inputs and better access to credit among the investors along the value chain would increase the level of return to the investment.

\section{References}

[1] Alasiri, K. O., Olaniyan F. O. and Salami A. 1998. Growth and Yield of Plantain as influenced by the application of Organic and Mineral Fertilizer. [Report]. - London and Basingstoke: Macmillian Publishers Ltd. - pp. 107-111.

[2] CBN 2003. Central Bank of Nigeria Statistical Bulletins and Annual Report.

[3] FAO, 2013 Food and Agriculture Organization of the United Nations. Crop yield. http://faostat.fao.org/site/567/DesktopDefault.aspx?PageID=5 67 \#ancor Idachaba Food Policy in Nigeria toward a Framework. [Journal]. - [s.1.]: Analysis Agricultural Research Bulletin, 1995. 77 (1).

[4] FAO, 2012: Commodity data, Country rankings. http://mongabay.com/commodities/data/category/1Production/1-Crops/489 plantains/51-
[5] Adejoro, M. A. Odubanjo, A. O. and Fagbola, B. O. (2010) Research Focus on Banana and Plantain (Musa spp.): Nigerian Perspectives Proc. IC on Banana \& Plantain in Africa, Acta Hort. 879, ISHS 2010.

[6] Idachaba, F. S. (1995). Food Policy in Nigeria towards a framework. Anal. Agric. Res. Bull., 77 (1): 161-166.

[7] Sanni, A. I, Ogbonna, D. N. 1991. The production of owoh-A Nigerian fermented seasoning agent from cotton seed (Gossypium hirsitiumL). Food Microbiol. 8: 223-229.

[8] Phillip, B, Shittu, A. M., Aiyelaagbe, I. O. O. and Adedokun, T. 2009. Economic potentials of plantain and fluted pumpkin intercropping as a poverty reduction strategy in South-western Nigeria. World J. Agric. Sci. 5 (5): 525-534.

[9] PIND, 2011. A report on Palm Oil Value Chain Analysis in the Niger Delta, Abuja: Foundation for Partnership Initiatives in the Niger Delta (PIND).

[10] Ferris, R. S. B. 1997. "Improving Storage Life of Plantain and Banana”. Research guide 62, IITA, Ibadan. Pp 8-12.

[11] Tijani, I. A., Omonona, B. T., Ashaolu, O. F., and Bamiro, O. M. 2009. Economic Analysis of Plantain Production in Irewole Local Government Area, Osun state, Nigeria. Journal Advances in Natural and Applied Sciences. pp. 183-187.

[12] Iyabo, B. A., Omobowale, A. O., Sulaiman, A. Y. and Kemisola, O. A. 2013. Plantain Value Chain Mapping in Southwestern Nigeria Journal of Economics and Sustainable Development ISSN 2222-1700 (Paper) ISSN 2222-2855.4 (16) (Online) www.iiste.org.

[13] Anamayi, S. E., Anamayi, R M., Sulieman, R. A. and Egbunu, J. O. 2010. Cost and Return Analysis for Small Scale Cane rat Production in Osun State, Nigeria. Proceedings of $11^{\text {th }}$ Annual National Conference of National Association of Agricultural Economics held at the Federal University of Technology, Minna Niger State, Nigeria $30^{\text {th }}$ November- $3^{\text {rd }}$ Decenmber.

[14] Olasunkanmi, J. B., Omitoyin, B. O. and Ipinmoroti, M. O. 2012. Social structure of fish farmers Osun State, SouthWestern Nigeria. Biological and Environmental Sciences Journal for the Tropics 9 (1).

[15] ICAP Group S. A., 2006. Financial Ratios Explanation, S. 1.: ICAP Group S. A.

[16] Egbodion, J. and Ahmadu, J. 2015. Production Cost Efficiency and Profitability of Abakaliki Rice in Ihialia Local Government Area of Anambra State, Nigeria. J. Appl. Sci. Environ. Manage. 19 (2) 327-333. 